\title{
Application of Photocatalyst Material Bentonite Ti Based as Antimicrobial Paint
}

\author{
Restu Kartiko Widi ${ }^{\mathrm{a}, 1}$, Emma Savitri ${ }^{\mathrm{a}}$, Arief Budhyantoro ${ }^{\mathrm{a}}$, Robert Yasaputera ${ }^{\mathrm{a}}$, Johan Gunardi ${ }^{\mathrm{a}}$ \\ ${ }^{a}$ Chemical Engineering Department, University of Surabaya, TG Building $5^{\text {th }}$ floor, Raya Kalirungkut Tenggilis, Surabaya, 60293, Indonesia \\ E-mail: ${ }^{1}$ restu@staff.ubaya.ac.id
}

\begin{abstract}
The TiO2-Fe3O4-bentonite was used in this study as a photocatalyst material for antimicrobial. The material was coated on a ceramic container. This study is the preliminary study on coatings formulated using TiO2-Fe3O4-bentonite to fight against microbial. This paper aims to emphasize the application of TiO2-Fe3O4-bentonite in the water purification process by adding material into the paint and coating it on ceramic containers as a reactor to help neutralize E. coli and S. Aureus. The TiO2-Fe3O4bentonite powder was synthesized by the sol-gel method. The photocatalyst powder was exhaled on the surface of the inside paintedwalls of the reactor. Some photo-catalytic parameters have been investigated, such as the photocatalyst concentrations and the initial concentration of E. coli starter, and S. Aureus starter. The result showed that the higher the concentration of the photocatalyst material, the more effective its degradation. Also, the highest death rate occurs when the initial concentration of the E. coli starter is at $107 \mathrm{CFU} / \mathrm{ml}$. Photo-degradation in gram-negative bacteria (E. Coli) gives more promising results than the process in gram-positive bacteria (S. aureus). The characterization of the material showed that the photocatalyst material leached during the photodegradation process. This causes the more extended the reaction takes place; there will be a decrease in bacterial photo-degradation activity. Also, the use of solar light in the photo-catalysis process is more effective than UV light.
\end{abstract}

Keywords — photo-catalytic; $\mathrm{TiO}_{2}-\mathrm{Fe}_{3} \mathrm{O}_{4}$-bentonite; E. Coli; S. Aureus; antimicrobial.

\section{INTRODUCTION}

The distillation of water from chemical pollutants and micro-organisms is an essential process to extract pure water. Conventional water treatment uses chlorine as a disinfectant. In general, the stages of water treatment are natural filtration and sedimentation, coagulation and flocculation, sedimentation, filtering, and disinfection. However, residual chlorine contained in the water after the disinfection process is hazardous if consumed by humans because of the presence of a carcinogenic matter [1].

Nowadays, the photo-catalytic method is widely used in the degradation of dyes and bacteria. One material that is widely studied is $\mathrm{TiO}_{2}$ due to its cost-effectiveness, chemical stability, high oxidizing ability, safety, and reusability [2][6]. Some researchers successfully showed the use of $\mathrm{TiO}_{2}$ as photocatalyst [7]-[12]. E. coli is a harmful microorganism which indicates the presence of bacteria in water. According to some studies, the use of photo-catalytic material with $\mathrm{TiO}_{2}$ or other metal oxides can inactivate this toxic bacterium [13]-[27].

In our previous work, we reported the use of $\mathrm{TiO}_{2}-\mathrm{Fe}_{3} \mathrm{O}_{4}$ bentonite as photocatalyst materials [28]-[31]. However, various problems tend to arise that need further treatment during the degradation process. This study is, therefore, a continuation of our initial report [32] and also the preliminary study on coatings formulated using $\mathrm{TiO}_{2}-\mathrm{Fe}_{3} \mathrm{O}_{4}$ bentonite to fight against microbial. This paper aims to emphasize on the application of $\mathrm{TiO}_{2}-\mathrm{Fe}_{3} \mathrm{O}_{4}$-bentonite in the water purification process by adding material into the paint and coating it on ceramic containers as a reactor to help neutralize E. coli and S. Aureus.

\section{MATERIAL AND METHOD}

\section{A. Materials}

\section{Ti-isopropoxide,}

$\mathrm{NH}_{4} \mathrm{OH}$,

$\mathrm{FeCl}_{2} \cdot 4 \mathrm{H}_{2} \mathrm{O}$, tetramethylammonium chloride, $\mathrm{FeCl}_{3} \cdot 6 \mathrm{H}_{2} \mathrm{O}$, ethanol and sodium hydroxide were used as materials for synthesizing of $\mathrm{TiO}_{2}-\mathrm{Fe}_{3} \mathrm{O}_{4}$-Bentonite photocatalyst. All these materials were purchased from Sigma-Aldrich. Bentonite clay was excavated from Pacitan, Indonesia.

\section{B. Methods}

$\mathrm{TiO}_{2}-\mathrm{Fe}_{3} \mathrm{O}_{4}$-bentonite has been prepared according to the method described in our previous work [31], [32]. PANalytical PW 3373/00 X'Pert X-ray was used to observe the crystalline phase of the photocatalyst material $(\mathrm{CuK} \alpha$, $1.54 \AA$, radiation at $30 \mathrm{~mA}$ and $40 \mathrm{kV}$ applied). At the same 
time, SEM FEI INSPECT S-50 was used to observe the topography and morphology.

The photo-degradation of bacteria was carried out in a 12 x $7 \times 3 \mathrm{~cm}$ ceramic container coated in water-based paint and sprayed with the photocatalyst material. The antimicrobial test was conducted by irradiating the bacterial suspension in a container with UV light at $\lambda=325 \mathrm{~nm}$ at a particular intensity for 180 minutes. $0.1 \mathrm{ml}$ of the solution is taken every 30 minutes (t). The sample was diluted, and the total number of bacteria counted using a Total Plate Count (TPC) method. The parameters studied were preliminary bacterial concentration (103-107 CFU/mL, namely $\mathrm{N}_{\mathrm{o}}$ ), a type of gram bacteria, and UV light source. The results of this TPC method will be obtained from the unwanted bacteria after treatment $(\mathrm{Nt})$. This would be acquired from the data at a constant rate of bacterial death, through the equation:

$$
\ln \frac{N t}{N o}=-k_{d} \cdot t
$$

The bacteria used are E. coli ATCC 25922, and S. aureus FNCC 0047.

\section{RESULTS AND DISCUSSIONS}

\section{A. Photocatalyst Characterization}

XRD characterization of photocatalysts has also been described in substantial details [31], [32]. The main peak on $2 \theta=30.3^{\circ}$ and $35,7^{\circ}$ refer to the crystal of the magnetite phase, and these were supported by $2 \theta=30.3$ and $43.5^{\circ}$. That of $2 \theta=26,6^{\circ}$ referred to $\mathrm{TiO}_{2}$ anatase phase. The intensity of anatase is smaller than the magnetite because $\mathrm{Ti}$ is less dominant than the Fe. While the peak at $2 \theta=9,9^{\circ}$; $13,0^{\circ} ; 19,8^{\circ}$; and $21,7^{\circ}$ refer to bentonite. Anatase and magnetite are the most important phase in the photo-catalytic process [10].

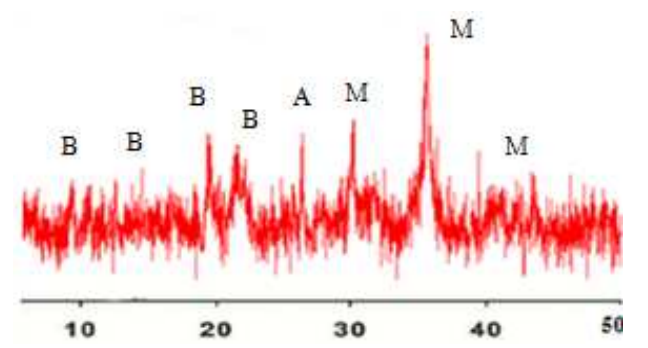

Fig. 1 XRD Photocatalyst Material Bentonite- $\mathrm{TiO}_{2}=\mathrm{Fe}_{3} \mathrm{O}_{4}$, (A) Anatase $\mathrm{TiO}_{2}$, (B) Bentonite, (M) Magnetite $\mathrm{Fe}_{3} \mathrm{O}_{4}$

\section{B. The E. coli and S. aureus bacterial growth}

According to Llorens et al. [33], the growth curve of bacteria can be divided into 4 phases, namely lag phase, exponential phase, stationary phase, and death phase. These bacteria growth curve represented by the optical density (OD) obtained through a spectrophotometer. In Fig. 2a, the E. coli growth curve grew, up to the 27 th hour, when only the exponential and stationary phases were obtained. The exponent phase of E. coli occurred from the first to the 12th hour. However, observations continue until the 27th hour when it reached the stationary phase of the growth of E. coli. In Fig. $2 b$, for the growth curve of bacteria S. aureus, it is apparent that there are four phases of growth discussed in the literature, namely the lag, exponential, stationary, and death phases. This phase of growth occurs for 4 hours, followed by an exponential state, which lasts up until the 10th hour. Furthermore, the bacteria stationary phase ran until the 18th hour and lasted till the death phase observations were carried out at the 27 th hour.

The growth curve of the bacteria was used to determine the hours it started entering the stationary or final phase, with those in the former used in carrying out this research. The reason for choosing this set of bacteria is because its growth rate equals the same as its mortality. The Photodegradation of bacteria is not affected by an increase or reduction in the number of bacteria naturally.


Fig. 2 (a) E. coli bacteria growth curve, (b) S. aureus bacteria growth curve

\section{Photo-catalytic test of Bentonite-TiO $\mathrm{O}_{2}-\mathrm{Fe}_{3} \mathrm{O}_{4}$ in terms of bacteria degrades}

1) Effect of Concentration Photocatalyst Material Bentonite $-\mathrm{TiO}_{2}-\mathrm{Fe}_{3} \mathrm{O}_{4}$ : The experiments were performed using the initial conditions of $E$. coli bacteria in the early stationary phase, an initial concentration of about $10^{6}$ $\mathrm{CFU} / \mathrm{ml}$, and photocatalyst material of $0.1 \mathrm{~g} / \mathrm{L}$ and $0.2 \mathrm{~g} / \mathrm{L}$. Irradiation is conducted using UV light with a wavelength of $354 \mathrm{~nm}$ and intensity of $1.8 \mathrm{~W} / \mathrm{m}^{2}$.

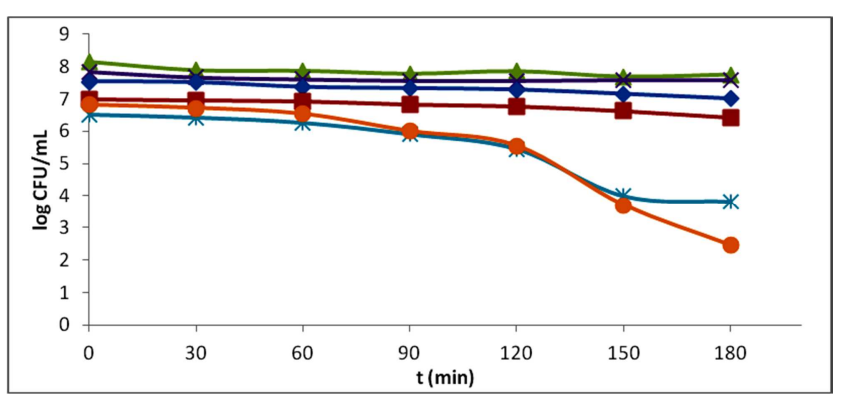

Fig. 3 Effect of Photocatalyst Concentration toward bacteria degradation $(-)$ UV Control, $(-)$ Bacteria Control, $(\rightarrow-)$ Material Control 0,1 gr/L, (- - ) Material Control 0,2 gr/L, ( *) Material Concentration Control 0,1 gr/L, $(\rightarrow)$ Material Concentration $0,2 \mathrm{gr} / \mathrm{L}$

The UV control was conducted using UV light, and that of bacteria was done without using UV lamps and in a dark room. Material control is carried out in the absence of UV irradiation light. As can be seen from Fig. 3, an insignificant decrease in the number of bacteria in the UV control indicates that the UV lamps used do not have a significant effect on the degradation of the E. coli. On the control, the material indicates no significant reduction in the number of bacteria inherent. Therefore, the photocatalyst material does not influence on the bacterial degradation. Also, the photocatalyst concentration does not affect decreasing the number of bacteria death if not irradiated by UV light, 
according to its constant rate values, as contained in Table 1 below.

TABLE I

DEATH RATE CONSTANT OF E.COLI BACTERIA (CONTROL)

\begin{tabular}{|c|c|}
\hline Control & Kd, mins $^{\mathbf{1}}$ \\
\hline Material Control 0,1 g/L & 0,007 \\
\hline Material Control 0,2 g/L & 0,006 \\
\hline UV Control & 0,004 \\
\hline Bacteria Control & 0,002 \\
\hline
\end{tabular}

In Fig. 3, in both the photocatalyst concentration of 0.1 $\mathrm{g} / \mathrm{L}$ and $0.2 \mathrm{~g} / \mathrm{L}$, the number of bacteria decreased significantly after 120 minutes. Between 0-120 minutes at concentrations of $0.1 \mathrm{~g} / \mathrm{L}$ and $0.2 \mathrm{~g} / \mathrm{L}$, the difference is not too visible. The decline in the number of these bacteria can be concluded for their photo-catalytic effect of the material used, that when irradiated by UV light, will degrade the bacteria. Mortality rate constants of E. coli can be seen from Table 2 below. The use of photo-catalysts results in an increased mortality rate of the bacteria owing to the numerous numbers of photocatalyst material used, resulting in the formation of free radicals. Therefore, the value of the rate constants for bacterial death concentration of $0.2 \mathrm{~g} / \mathrm{L}$ is higher than that of $\mathrm{E}$. coli degradation test with a concentration of $0.2 \mathrm{~g} / \mathrm{L}$.

TABLE II

Death Rate CONSTANT OF E. Coli BaCteria (PhOto-CATAlyst)

\begin{tabular}{|c|c|}
\hline Photocatalyst concentration (g/L) & Kd, mins $^{-1}$ \\
\hline 0,1 & 0,058 \\
\hline 0,2 & 0,118 \\
\hline
\end{tabular}

2) Effect of Initial Concentration of E. coli Bacteria: Fig. 4 shows that the three controlled trials, a significant decline in the number of bacteria, thereby decreasing the number caused by the photo-catalytic reaction.

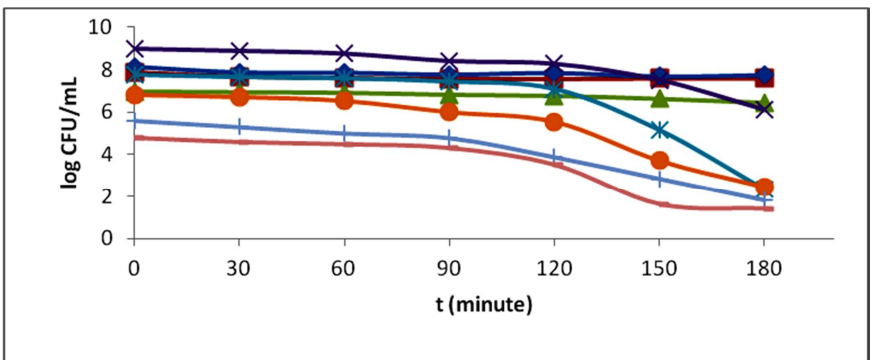

Fig. 4 Effect of Initial Concentration Bacteria E. coli toward Degradation Bacteria, $(\rightarrow)$ Control UV, $(-)$ Control Bacteria, $\left({ }^{-}\right)$Control Material $0,2 \mathrm{gr} / \mathrm{L},(\div)$ Concentration $10^{8} \mathrm{CFU} / \mathrm{mL},\left(*^{k}\right)$ Concentration $10^{7}$ $\mathrm{CFU} / \mathrm{mL},(\rightarrow-)$ Concentration $10^{6} \mathrm{CFU} / \mathrm{mL},(-)$ Concentration $10^{5}$ $\mathrm{CFU} / \mathrm{mL},(-)$ Concentration $10^{4} \mathrm{CFU} / \mathrm{mL}$

The number of bacteria is decreasing as shown in Fig. 4; each initial concentration has the same trend, leading to a limited number of decreases in the number of bacteria in the first hour. After an hour, there is a significant amount of decrease in the number of bacteria. This result is because, in the bacterial cell, there are two kinds of enzyme, the catalase (CAT) and superoxide dismutase (SOD). These two can convert free radicals that attack bacteria into harmless components, thereby reducing the photo-catalytic effect.
However, the defense of bacteria by the two enzymes will be reduced and depleted due to the increasing number of free radicals formed from the photocatalyst material caused by UV light. This damage and destroys the bacteria after the first 1 hour. The death rate constants value of $E$. coli bacteria can be seen in Table 3 below.

TABLE III

DEATH RATE CONSTANT OF E. COLI BACTERIA (EFFECT OF BACTERIA CONCENTRATION)

\begin{tabular}{|c|c|}
\hline Bacteria Concentration (CFU/mL) & Kd, $_{\text { }} \mathbf{m i n s}^{-\mathbf{1}}$ \\
\hline $10^{8}$ & 0,083 \\
\hline $10^{7}$ & 0,181 \\
\hline $10^{6}$ & 0,118 \\
\hline $10^{5}$ & 0,076 \\
\hline $10^{4}$ & 0,081 \\
\hline
\end{tabular}

The death rate of bacteria is equivalent to its initial concentration (Fig. 4). The lower the concentration, the shorter the time required, and the higher the concentration, the longer the time needed. The higher the initial bacteria concentration, the longer the time required for photodegradation activity. This result is due to the total bacteria in the river is about $10^{3}-10^{5} \mathrm{CFU} / \mathrm{mL}$, and compared to the stationary phase $( \pm 10$ hours), photo-catalytic material Bentonite- $\mathrm{TiO}_{2}-\mathrm{Fe}_{3} \mathrm{O}_{4}$ is very effective to degrade in just about 3 hours.

3) Effect of the Gram Bacteria on the Degradation Process: In this study, two types of gram bacteria were used, i.e. Staphylococcus aureus as gram-positive and E. Coli as gram-negative bacteria.

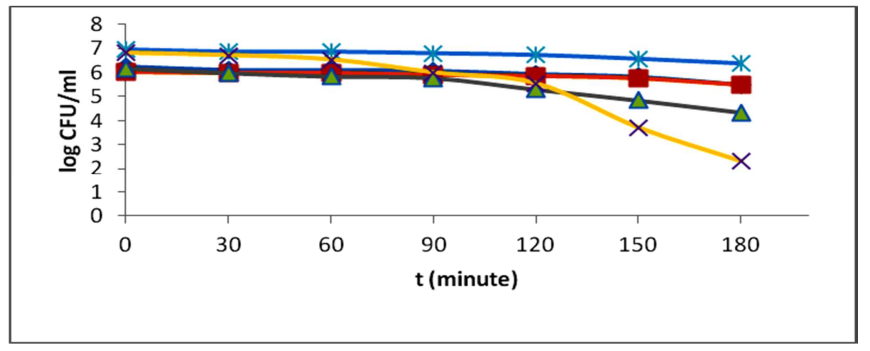

Fig. 5 Degradation activity test on different types of bacteria, $(\rightarrow-)$ Control bacteria Sauers, ( - - ) Control UV, ( $\rightarrow$ ) Control Material, ( $\left.{ }^{-}\right)$Bacteria S. aureus, ( $\longrightarrow$ Bacteria E. coli

In Fig. 5, it can be observed that the control of bacterial, material, and UV, is relatively constant. Therefore, it can be concluded that in the control process, the bacteria are not degraded. In the bacteria $S$. aureus, the curve is constant for 90 minutes (Fig 5). Meanwhile, when compared with E. coli, the curve looks constant for 60 minutes. Furthermore, to have its defense system to attack from a harmful substance, the structure of the cell wall will serve as resistance against any harmful substance. Its cell wall is composed of three kinds of layers, the outer membrane, peptidoglycan, and inner cell membrane. Peptidoglycan on the gram-negative is about 2-7 nm, which is relatively thin. In gram-positive bacteria, the cell wall primarily consists of two sections, namely the peptidoglycan layer and the inner membrane. Its peptidoglycan layer is thicker than that of gram-negative, which is $20-80 \mathrm{~nm}$. In this photo-catalytic process, ROS generated will make direct contact with the cell wall of the 
bacteria; the gram-positive bacteria have a stronger resistance when compared to that of the negative. When ROS oxidizes with the bacterial cell wall, it is broken, and the cells will suffer from lysis, ROS will go further into the interior of the cell, which then oxidizes Coenzyme-A. This is very important to produce protein synthesis and respiration in the bacteria so that if the part is damaged, the cell will die.

TABLE IV

Death Rate Constant Value of E. Coli and S. Aureus

\begin{tabular}{|c|c|}
\hline Bacteria & Kd, $\mathbf{m i n s}^{\mathbf{- 1}}$ \\
\hline Staphylococcus aureus & 0,036 \\
\hline Escherichia coli & 0,118 \\
\hline
\end{tabular}

From Table 4, the value of the rate constant of $S$. aureus bacterial death is smaller than E. coli. Therefore, the degradation effect caused by the photocatalyst material Bentonite- $\mathrm{Fe}_{3} \mathrm{O}-\mathrm{TiO}_{2}$ is more effective to E. coli.

4) Effect of Solar Irradiance on the Degradation Process: In this research, the effectiveness of the photocatalyst material (Bentonite- $\mathrm{Fe}_{3} \mathrm{O}_{4}-\mathrm{TiO}_{2}$ ), in the degrading bacteria was conducted using solar radiation. The research was performed using $E$. coli bacteria at the beginning of the stationary phase, with an initial concentration of $10^{6} \mathrm{CFU} /$ $\mathrm{mL}$. The experiment was conducted in August 2019 from 10:30 to $13: 30$.

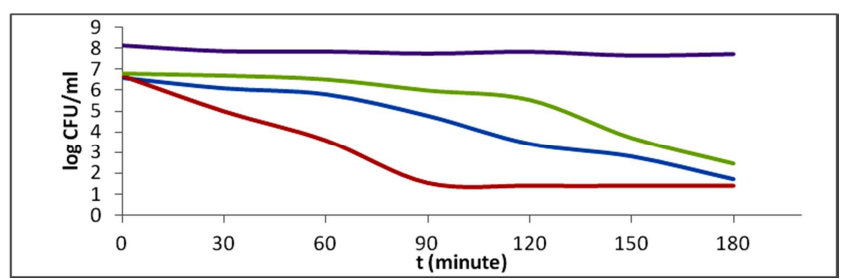

Fig. 6 Photo-catalytic degradation test of E.coli using solar radiation

( ${ }^{-}$) Control UV, ( $\left(^{-}\right)$Photocatalysis using UV, (-) Control Solar radiation, ( $)$ Photocatalysis using solar radiation

Fig. 6 shows the control from the solar radiation alone without any photocatalyst material, which results in the number of bacteria, is also decreased significantly from the concentration of $10^{6} \mathrm{CFU} / \mathrm{ml}$ to $\pm 50 \mathrm{CFU} / \mathrm{ml}$ in 180 minutes. Meanwhile, if the photocatalyst material is applied, with an initial bacterial concentration of $10^{6} \mathrm{CFU} / \mathrm{ml}$, it decreases to $0 \mathrm{CFU} / \mathrm{ml}$ only within \pm 90 minutes. The continuous line on the results with solar radiation above indicates that the bacteria have degraded. This result happens because when the water temperature is exposed to solar radiation, it increases up to $42^{\circ} \mathrm{C}$ so that $E$. coli can be degraded [20]. Additionally, the intensity of the sun reaches $80-90 \mathrm{~W} / \mathrm{m}^{2}$ on the date and time of the experiment. This result exceeded the reaction occurrence limit, thus causing degradation of bacteria significantly.

The intensity of sunlight is not in a constant condition because it depends on the weather, time, and season. The photo-catalytic process solar radiation allows bacteria to flourish again after the irradiation process. Additionally, some pathogenic bacteria are resistant to solar radiation. The sunlight has a wide wavelength range, from $310-2300 \mathrm{~nm}$, capable of generating ROS is the range of $320-450 \mathrm{~nm}$.
There is a constant bacterial death with an insignificant difference to the UV obtained from the sun comparing the value of kd (Table 5). Even though in theory, the value of $\mathrm{kd}$ by UV photo-catalytic process should be higher when compared with that of solar radiation. The result above is because of the massive intensity of solar light which causes death rate value equating to that of UV radiation.

TABLE V

DeAth Rate Constant VAlue of E. Coli (EFFECT OF RADiation)

\begin{tabular}{|c|c|}
\hline Type of Light Irradiation & Kd, mins $^{-1}$ \\
\hline UV & 0,118 \\
\hline Solar & 0,128 \\
\hline
\end{tabular}

D. The Chalking Effect of Wall Paint's Binder Due to the photo-catalytic reaction Photo-catalyst Material Bentonite- $\mathrm{TiO}_{2}-\mathrm{Fe}_{3} \mathrm{O}_{4}$

Scanning Electron Microscopy (SEM) in this study was conducted to observe the surface structure of Bentonite$\mathrm{Fe}_{3} \mathrm{O}_{4}-\mathrm{TiO}_{2}$ before and after the photocatalyst.
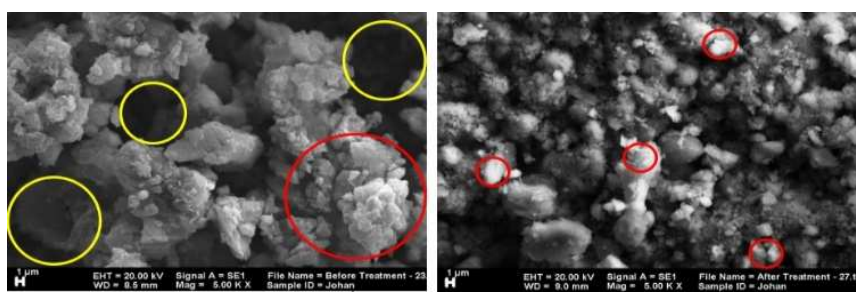

Fig. 7 SEM morphology of the surface of Materials Photocatalyst Bentonite- $\mathrm{Fe}_{3} \mathrm{O}_{4}-\mathrm{TiO}_{2}$; (a) Before, and (b) After Photocatalytic Reaction; (○) Pores of Bentonite, $(\bigcirc)$ Materials $\mathrm{TiO}_{2}$ and $\mathrm{Fe}_{3} \mathrm{O}$

In Fig. 7a, before the material was used to test the applications, paint binders could be seen covering the surface of the catalyst. However, after its utilization, the bentonite pores are mostly closed and more scattered. This is due to damage to the paint binder.

TABLE VI

Edx CHARACTERIZATION OF MATERIAL PHOTOCATALyTIC BENTONITE$\mathrm{TIO}_{2}-\mathrm{FE}_{3} \mathrm{O}_{4}$ BEFORE AND AFTER PHOTOCATALYTIC REACTION

\begin{tabular}{|c|c|c|}
\hline Element & \multicolumn{2}{|c|}{ Weight \% } \\
\hline & Before reaction & After reaction \\
\hline$T i$ & 1.94 & 0.60 \\
\hline$F e$ & 8.17 & 1.23 \\
\hline
\end{tabular}

According to the EDX characterization, after the photocatalyst material was used in degrading the bacteria, the $T i$ and Fe content were reduced, as seen in Table 6. This result happens because when the procedure progresses, the resultant ROS manufactured by the photocatalyst can degrade the binder and pigment as an organic substance. This process is known as chalking effects or calcification. Damage to the paint pigment and binder, which resulted in the production of $\mathrm{Ti}$ and $\mathrm{Fe}$, and initially bonded with a binder, becomes loose and dispersed. The liberation of $\mathrm{TiO}_{2}$ makes the material becomes more widespread, as shown in Fig. $7 \mathrm{~b}$. The pores on bentonite are covered by the binder and paint pigment with some wasted as a result of the water in the tub made the content of $T i$ and $F e$ reduced. 


\section{CONCLUSION}

Photocatalyst method using bentonite material- $\mathrm{Fe}_{3} \mathrm{O}_{4}$ $\mathrm{TiO}_{2}$ with the aid of UV light can degrade $E$. coli and $S$. aureus. The optimum concentration of the photocatalyst material in the degrading bacteria was $0,2 \mathrm{gr} / \mathrm{L}$. By using a material concentration $0,2 \mathrm{gr} / \mathrm{L}$, the highest rate constants of E. coli bacteria were obtained at $10^{7}$ is equal to $0.181 \mathrm{~L} / \mathrm{min}$. The higher the initial concentration of bacteria, the longer the time it takes to degrade the bacteria. The photo-catalytic process is more effective in degrading gram-negative bacteria compare to a gram-positive. The use of solar light in the photo-catalysis process is more effective than UV light.

\section{ACKNOWLEDGMENT}

Authors would like to thank the Directorate General Strengthening Research and Development, Indonesian Ministry of Research, Technology and Higher Education for providing financial support through PTUPT Grant 2019 contract no: 004/SP2H/LT/MONO/L7/2019 on 26 March 2019.

\section{REFERENCES}

[1] M. J. Rodriguez and J. B. Sérodes, "Assessing empirical linear and non-linear modelling of residual chlorine in urban drinking water systems," Environ. Model. Softw., vol. 14, no. 1, pp. 93-102, 1998, doi: 10.1016/S1364-8152(98)00061-9.

[2] C. Luo, X. Ren, Z. Dai, Y. Zhang, X. Qi, and C. Pan, "Present Perspectives of Advanced Characterisation Techniques in TiO2Based Photo-catalysts," ACS Applied Materials and Interfaces, vol. 9, no. 28. pp. 23265-23286, 2017, doi: 10.1021/acsami.7b00496.

[3] Z. Wang, P. Feng, H. Chen, and Q. Yu, "Photo-catalytic performance and dispersion stability of nanodispersed $\mathrm{TiO} 2$ hydrosol in electrolyte solutions with different cations," J. Environ. Sci. (China), vol. 88, pp. 59-71, 2020, doi: 10.1016/j.jes.2019.07.013.

[4] C. Ma, X. Wang, H. Luo, and D. Zhang, "Synthesis of Ag/TiO2 core-shell nanowires with enhanced stability of photo-catalytic activity," J. Mater. Sci. Mater. Electron., vol. 28, no. 14, pp. 1071510719, 2017, doi: 10.1007/s10854-017-6847-0.

[5] B. C. B. Salgado, R. A. Cardeal, and A. Valentini, "Photocatalysis and Photo-degradation of Pollutants," in Nanomaterials Applications for Environmental Matrices, 2019, pp. 449-488.

[6] H. Zhao, F. Pan, and Y. Li, "A review on the effects of TiO2 surface point defects on $\mathrm{CO} 2$ photoreduction with $\mathrm{H} 2 \mathrm{O}$," Journal of Materiomics, vol. 3, no. 1. pp. 17-32, 2017, doi: 10.1016/j.jmat.2016.12.001.

[7] Z. Chen, H. Liu, and J. Su, "Titanium Oxide Photocatalytic Materials and Their Applications in Ceramics," Ceram. Sci. Eng., vol. 1, no. 1, 2018, doi: 10.24294/cse.v1i1.286.

[8] C. Yang et al., "Highly-efficient photo-catalytic degradation of methylene blue by PoPD-modified $\mathrm{TiO} 2$ nanocomposites due to photosensitisation-synergetic effect of TiO2 with PoPD," Sci. Rep., vol. 7, no. 1, 2017, doi: 10.1038/s41598-017-04398-x.

[9] C. Yang et al., "Enhanced photo-catalytic activity of PANI/TiO2 due to their photosensitisation-synergetic effect," Electrochim. Acta, vol. 247, pp. 486-495, 2017, doi: 10.1016/j.electacta.2017.07.037.

[10] N. S. Allen, N. Mahdjoub, V. Vishnyakov, P. J. Kelly, and R. J. Kriek, "The effect of crystalline phase (anatase, brookite and rutile) and size on the photo-catalytic activity of calcined polymorphic titanium dioxide (TiO2)," Polym. Degrad. Stab., vol. 150, pp. 31-36, 2018, doi: 10.1016/j.polymdegradstab.2018.02.008.

[11] M. Söyleyici Cergel and F. Atay, "The role of the annealing process in different gas environments on the degradation of the methylene blue organic pollutant by brookite-TiO2 photocatalyst," Ionics (Kiel)., vol. 25, no. 8, pp. 3823-3836, 2019, doi: 10.1007/s11581-01902941-6.

[12] C. Li et al., "Extraordinary catalysis induced by titanium foil cathode plasma for degradation of water pollutant," Chemosphere, vol. 214, pp. 341-348, 2019, doi: 10.1016/j.chemosphere.2018.09.138.

[13] N. Doss, G. Carré, V. Keller, P. André, and N. Keller, "Photocatalytic Decontamination of Airborne T2 Bacteriophage
Viruses in a Small-Size TiO2/B-SiC Alveolar Foam LED Reactor," Water. Air. Soil Pollut., vol. 229, no. 2, 2018, doi: 10.1007/s11270017-3676-y.

[14] C. Ai, S. C. Wu, L. Y. Li, Y. Lei, and X. Shao, "Novel magnetically separable $\gamma$-Fe2O3/Ag/AgCl/g-C3N4 composite for enhanced disinfection under visible light," Colloids Surfaces A Physicochem. Eng. Asp., vol. 583, 2019, doi: 10.1016/j.colsurfa.2019.123981.

[15] J. J. Murcia, E. G. Ávila-Martínez, H. Rojas, J. A. Navío, and M. C. Hidalgo, "Study of the E. coli elimination from urban wastewater over photocatalysts based on metallized TiO2," Appl. Catal. B Environ., vol. 200, pp. 469-476, 2017, doi: 10.1016/j.apcatb.2016.07.045.

[16] J. Mac Mahon, S. C. Pillai, J. M. Kelly, and L. W. Gill, "Solar photocatalytic disinfection of E. coli and bacteriophages MS2, ФX174 and PR772 using $\mathrm{TiO} 2, \mathrm{ZnO}$ and ruthenium based complexes in a continuous flow system," J. Photochem. Photobiol. B Biol., vol. 170, pp. 79-90, 2017, doi: 10.1016/j.jphotobiol.2017.03.027.

[17] S. Giannakis et al., "Iron oxide-mediated semiconductor photocatalysis vs. heterogeneous photo-Fenton treatment of viruses in wastewater. Impact of the oxide particle size.," J. Hazard. Mater., vol. 339, pp. 223-231, 2017, doi: 10.1016/j.jhazmat.2017.06.037.

[18] Y. Yamaguchi et al., "Selective Inactivation of Bacteriophage in the Presence of Bacteria by Use of Ground Rh-Doped SrTiO3 Photocatalyst and Visible Light," ACS Appl. Mater. Interfaces, vol. 9, no. 37, pp. 31393-31400, 2017, doi: 10.1021/acsami.7b07786.

[19] X. Zheng, Z. P. Shen, C. Cheng, L. Shi, R. Cheng, and J. Dong, "Electrospinning $\mathrm{Cu}-\mathrm{TiO} 2$ nanofibers used for photo-catalytic disinfection of bacteriophage f2: Preparation, optimisation and characterisation," RSC Adv., vol. 7, no. 82, pp. 52172-52179, 2017, doi: 10.1039/c7ra07770j.

[20] X. Zheng, Z. peng Shen, C. Cheng, L. Shi, R. Cheng, and D. hai Yuan, "Photo-catalytic disinfection performance in virus and virus/bacteria system by $\mathrm{Cu}-\mathrm{TiO} 2$ nanofibers under visible light," Environ. Pollut., vol. 237, pp. 452-459, 2018, doi: 10.1016/j.envpol.2018.02.074.

[21] P. Ganguly, C. Byrne, A. Breen, and S. C. Pillai, "Antimicrobial activity of photocatalysts: Fundamentals, mechanisms, kinetics and recent advances," Applied Catalysis B: Environmental, vol. 225. pp. 51-75, 2018, doi: 10.1016/j.apcatb.2017.11.018.

[22] C. S. Uyguner Demirel, N. C. Birben, and M. Bekbolet, "A comprehensive review on the use of second generation $\mathrm{TiO} 2$ photocatalysts: Micro-organism inactivation," Chemosphere, vol. 211. pp. 420-448, 2018, doi: 10.1016/j.chemosphere.2018.07.121.

[23] P. V. Laxma Reddy, B. Kavitha, P. A. Kumar Reddy, and K. H. Kim, "TiO2-based photo-catalytic disinfection of microbes in aqueous media: A review," Environmental Research, vol. 154. pp. 296-303, 2017, doi: 10.1016/j.envres.2017.01.018.

[24] M. J. Abeledo-Lameiro, A. Reboredo-Fernández, M. I. Polo-López, P. Fernández-Ibáñez, E. Ares-Mazás, and H. Gómez-Couso, "Photocatalytic inactivation of the waterborne protozoan parasite Cryptosporidium parvum using $\mathrm{TiO} 2 / \mathrm{H} 2 \mathrm{O} 2$ under simulated and natural solar conditions," Catal. Today, vol. 280, pp. 132-138, 2017, doi: $10.1016 /$ j.cattod.2016.05.046

[25] V. Binas, D. Venieri, D. Kotzias, and G. Kiriakidis, "Modified TiO2 based photocatalysts for improved air and health quality," Journal of Materiomics, vol. 3, no. 1. pp. 3-16, 2017, doi: 10.1016/j.jmat.2016.11.002.

[26] R. Hendili, A. Alatrache, M. Ben-Attia, and M. N. Pons, "Antibacterial inactivation of spiramycin after titanium dioxide photo-catalytic treatment," Comptes Rendus Chim., vol. 20, no. 7, pp. 710-716, 2017, doi: 10.1016/j.crci.2017.02.007.

[27] T. T. T. Huyen, T. T. K. Chi, N. D. Dung, H. Kosslick, and N. Q. Liem, "Enhanced photo-catalytic activity of $\{110\}$-faceted $\mathrm{TiO} 2$ rutile nanorods in the photo-degradation of hazardous pharmaceuticals," Nanomaterials, vol. 8, no. 5, 2018, doi: 10.3390/nano8050276.

[28] R. K. Widi, A. Budhyantoro, and E. Savitri, "Use of TiO2-Fe3O4 pillared bentonite as photocatalyst in photo-degradation of basic blue," J. Chem. Pharm. Res., vol. 7, no. 9, pp. 183-188, 2015.

[29] E. Savitri, R. K. Widi, and A. Budhyantoro, "The effect of the calcinations temperature during synthesis of $\mathrm{TiO} 2-\mathrm{Fe} 3 \mathrm{O} 4-$ bentonite as photocatalyst material," J. Chem. Pharm. Res., vol. 7, no. 9, pp. 70-75, 2015.

[30] R. K. Widi and A. Budhyantoro, "Catalytic performance of TiO2Fe3O4 supported bentonite for photo-catalytic degradation of phenol," Int. J. Appl. Eng. Res., vol. 9, no. 23, pp. 18753-18758, 2014. 
[31] R. Kartiko Widi, I. Suciani, E. Savitri, R. Reynaldi, and A. Budhyantoro, "Photo-catalytic decolorisation of Basic Blue 41 using TiO2-Fe3O4-bentonite coating applied to ceramic in continuous system," Chem. Eng. Commun., vol. 207, no. 2, pp. 203-212, 2020, doi: 10.1080/00986445.2019.1578756.

[32] R. K. Widi, E. Savitri, O. Angelina, O. J. S. Caroline, and A. Budhyantoro, "Antibacterial inactivation of Escherichia coli after
TiO2-Fe3O4-Bentonite photo-catalytic treatment," Int. J. Adv. Sci. Eng. Inf. Technol., vol. 8, no. 6, pp. 2367-2373, 2018, doi: 10.18517/ijaseit.8.6.3884.

[33] J. M. Navarro Llorens, A. Tormo, and E. Martínez-García, "Stationary phase in gram-negative bacteria," FEMS Microbiology Reviews, vol. 34, no. 4. pp. 476-495, 2010, doi: 10.1111/j.15746976.2010.00213.x. 